\title{
Determination of the As(III)/As(V) Ratio in Soil by X-ray Absorption Near-edge Structure (XANES) and Its Application to the Arsenic Distribution between Soil and Water
}

\author{
Yoshio Takahashi, ${ }^{* \dagger}$ Naoya Ohtaku,* Satoshi Mitsunobu,* Kouichi Yuita, ** \\ and Masaharu NoMURA*** \\ *Department of Earth and Planetary Systems Sci., Graduate School of Sci., Hiroshima University, \\ Higashi-Hiroshima, Hiroshima 739-8526, Japan \\ **National Institute for Agro-Environmental Sciences (NIAES), Tsukuba, Ibaraki 305-8604, Japan \\ ***Photon Factory, Institute of Materials Structure Sci., KEK, Oho, Tsukuba, Ibaraki 305-0801, Japan
}

\begin{abstract}
The details of a method used to determine the $\mathrm{As}(\mathrm{III}) / \mathrm{As}(\mathrm{V})$ ratio in soil by arsenic K-edge XANES spectroscopy are described. The spectra of mixtures of $\mathrm{NaAs}(\mathrm{III}) \mathrm{O}_{2}$ and $\mathrm{NaH}_{2} \mathrm{As}(\mathrm{V}) \mathrm{O}_{4}$, conducted for an $\mathrm{As}(\mathrm{III}) / \mathrm{As}(\mathrm{V})$ calibration, were well-fitted by combining normalized spectra of $\mathrm{NaAsO}_{2}$ and $\mathrm{Na}_{2} \mathrm{HAsO}_{4}$, where the coefficients multiplied by the normalized spectra were identical to the molar ratio of $\mathrm{As}(\mathrm{III})$ and $\mathrm{As}(\mathrm{V})$ in the mixtures. XANES spectra of arsenic in soil samples could also be fitted by a linear combination of the spectra of $\mathrm{NaAsO}_{2}$ and $\mathrm{Na}_{2} \mathrm{HAsO}_{4}$, which enabled us to estimate the $\mathrm{As}(\mathrm{III}) / \mathrm{As}(\mathrm{V})$ in a soil containing $10.2 \mathrm{mg} / \mathrm{kg}$ arsenic. The As(III)/As(V) ratio in the soil was compared with that of a soil solution contacted with the soil determined by HPLC-ICP-MS, showing that As(III) is distributed to water more readily than $\mathrm{As}(\mathrm{V})$. The application of the XANES method is important for a better understanding of the behavior of $\mathrm{As}(\mathrm{III})$ and $\mathrm{As}(\mathrm{V})$ independently in a natural aquifer.
\end{abstract}

(Received March 10, 2003; Accepted March 26, 2003)

\section{Introduction}

Arsenic is one of the most toxic elements in the environment, and has been of great interest in environmental studies., ${ }^{1,2}$ In particular, naturally occurring arsenic contamination in groundwater in the Ganges delta plain has been a great issue, and has received significant attention. ${ }^{1-3}$ It has often been discussed that the dissolution of an iron (hydr)oxide phase containing a large amount of arsenic is an important process for the contamination of arsenic in a reductive condition, such as in ground water. ${ }^{1}$ In addition, it has also been indicated that the high mobility of $\mathrm{As}(\mathrm{III})$ compared with $\mathrm{As}(\mathrm{V})$ is another essential factor concerning the high concentration of arsenic in ground water. However, a quantitative comparison of these two factors is not easy, partly because there have not been many studies on the speciation of arsenic in the solid phase, whereas speciation in the aqueous phase has been conducted more readily by HPLC-ICP-MS or the hydride generation method coupled with atomic absorption spectroscopy or ICP-AES., ${ }^{1,4-6}$ In this study, we employed XANES (X-ray absorption nearedge structure) to determine the $\mathrm{As}(\mathrm{III}) / \mathrm{As}(\mathrm{V})$ ratio in the solid phase, and applied it to arsenic distribution experiments between the soil and water phases. Although there have been some papers on the speciation of arsenic by XANES, ${ }^{7-10}$ most of them do not include details of the quantitative analysis of the $\mathrm{As}(\mathrm{III}) / \mathrm{As}(\mathrm{V})$ ratio for solid media. For example, the difference in the X-ray absorption cross section of white line peaks for the

† To whom correspondence should be addressed.

E-mail: takahasi@geol.sci.hiroshima-u.ac.jp
$\mathrm{As}(\mathrm{III})$ and $\mathrm{As}(\mathrm{V})$ species must be assessed, since this factor can alter the ratio of different species as can be seen in the case of sulfur when XANES is employed for speciation work. ${ }^{11,12}$

In this study, the $\mathrm{As}(\mathrm{III}) / \mathrm{As}(\mathrm{V})$ ratio in the aqueous phase was also determined by HPLC-ICP-MS. The determinations of $\mathrm{As}(\mathrm{III})$ and $\mathrm{As}(\mathrm{V})$ in both the aqueous and solid phases enable us to compare the soil-water distribution coefficients independently for $\mathrm{As}(\mathrm{III})$ and $\mathrm{As}(\mathrm{V})$, which will produce important information to understand the behavior of arsenic in the environment.

\section{Experimental}

\section{Reagents and minerals}

Four arsenic compounds were used as standard materials for XANES: oxides $\left(\mathrm{As}_{2} \mathrm{O}_{3}\right.$ and $\left.\mathrm{As}_{2} \mathrm{O}_{5}\right)$ and sodium salts $\left(\mathrm{NaAs}(\mathrm{III}) \mathrm{O}_{2}\right.$ and $\left.\mathrm{Na}_{2} \mathrm{HAs}(\mathrm{V}) \mathrm{O}_{4} \cdot 7 \mathrm{H}_{2} \mathrm{O}\right)$. The purity of the starting reagents, purchased from Sigma-Aldrich, Inc. (oxides) and Wako Chem. Ind. (sodium salts), were more than 99\%, except for $\mathrm{NaAsO}_{2}$. The purity of $\mathrm{NaAsO}_{2}$ measured in this study was $93.1 \%$, determined by ICP-MS, which was taken into account to determine the $\mathrm{As}(\mathrm{III}) / \mathrm{As}(\mathrm{V})$ ratio in the calibration. In order to compare arsenic species sorbed on soil with naturally occurring arsenic minerals, four minerals were received from Hori Mineralogy (Tokyo, Japan), which were confirmed by XRD. The minerals were arsenopyrite (FeAsS), realger (AsS), adamite $\left(\mathrm{Zn}_{2}\left(\mathrm{AsO}_{4}\right)(\mathrm{OH})\right)$, and erythrite $\left((\mathrm{Co}, \mathrm{Ni})_{3}\left(\mathrm{AsO}_{4}\right)_{2} \cdot 8 \mathrm{H}_{2} \mathrm{O}\right)$. The As(III) standard solution $\left(1000 \mathrm{mg} / \mathrm{dm}^{3}\right)$ received from Spex Certi Prep, Inc. was also included in the reference materials. 


\section{XANES spectroscopy}

Arsenic K-edge XANES spectroscopy was employed to determine the $\mathrm{As}(\mathrm{III}) / \mathrm{As}(\mathrm{V})$ ratio in soil samples. XANES spectra were measured at BL-12C of Photon Factory (PF) under the condition of $2.5 \mathrm{GeV}, 450-300 \mathrm{~mA}^{13} \mathrm{X}$-rays were monochromatized with an $\mathrm{Si}(111)$ double-crystal monochromator and then focused to $1 \times 0.5 \mathrm{~mm}^{2}$ with a bent cylindrical mirror, which also reduced the higher orders. For all experiments, $\mathrm{As}_{2} \mathrm{O}_{3}$ was used as an energy reference material, where we set the energy of the white line peak maximum of $\mathrm{As}_{2} \mathrm{O}_{3}$ at 11.866 $\mathrm{keV}$. The relative energy to this peak was employed to display the XANES spectra in this paper. Arsenic K-edge XANES spectra were recorded in the energy range between 11.830 and $11.920 \mathrm{keV}$, except for $\mathrm{NaAsO}_{2}$ and $\mathrm{Na}_{2} \mathrm{HAsO}_{4} \cdot 7 \mathrm{H}_{2} \mathrm{O}$, for which we measured EXAFS. The energy step was typically $0.25 \mathrm{eV}$ at the XANES region. The energy of the peak top did not shift by more than $0.25 \mathrm{eV}$ throughout all of the measurements. All spectra were collected in the fluorescence mode with the sample positioned at $45^{\circ}$ with respect to the beam. The fluorescence yield was measured using a 19-element Ge semiconductor detector (SSD). The detection system of the SSD was reported elsewhere. ${ }^{14,15}$ A shaping time of $0.25 \mu$ s was adopted for the counting system in this study. Windows of SCAs were tuned to count the arsenic K-line fluorescence selectively. The total count entering the detector (ICR: incoming count rate) was kept lower than $200 \mathrm{kcps}$ by adjusting the distance between the SSD and the sample. It was necessary to correct the SCA windowed signal due to the increase in the dead time when the ICR was increased by large intensities of the fluorescence and scattering X-rays. The correction was made by the code CORDT3U. ${ }^{14,15}$

\section{$H P L C-I C P-M S$}

The $\mathrm{As}(\mathrm{III}) / \mathrm{As}(\mathrm{V})$ ratio in a soil solution was determined by HPLC connected to ICP-MS (VG PQ-3). The pump and oven used were a Pu-2089 Plus (JASCO) and a Co-2065 Plus (JASCO), respectively. The experimental condition was similar to that described by Donais. ${ }^{5}$ An ODS column (CrestPak C18T5; inner diameter $4.6 \mathrm{~mm}$; length $250 \mathrm{~mm}$ ) was used at $40^{\circ} \mathrm{C}$. The mobile phase optimized in our laboratory was $\mathrm{pH} 8$ water, containing $0.050 \%$ methanol, $0.20 \mathrm{mM}$ Tris buffer, and 0.30 $\mathrm{mM}$ tetrabutylammonium phosphate as an ion-pair reagent. The flow rate was $1.0 \mathrm{ml} / \mathrm{min}$. The As(III) peak was observed at around $3.5 \mathrm{~min}$, while $\mathrm{As}(\mathrm{V})$ was at $5.8 \mathrm{~min}$. Organoarsenic species were not observed in the soil solution examined in this study.

\section{Soil incubation experiments}

Soil incubation experiments were conducted based on a method described by Yuita et al. ${ }^{16}$ The soil sample used in this study was surface soil (plowed horizon) of a paddy field of the National Institute for Agro-Environmental Sciences (NIAES) at Tsukuba, Japan. The sample was air-dried and sieved $(2 \mathrm{~mm})$. Some characteristics of the soil sample are tabulated in Table 1. The concentration of arsenic in the soil was $10.2 \mathrm{mg} / \mathrm{kg} .{ }^{19}$ The free water content involved in an air-dried soil sample was $4.90 \%$, determined by drying soil sample at $110^{\circ} \mathrm{C}$. A $10.0 \mathrm{~g}$ portion of the soil sample, $9.51 \mathrm{~g}$ as dried weight $\left(110^{\circ} \mathrm{C}\right)$, was mixed with various amounts of Milli-Q water in a plastic cylindrical bottle. The water content was defined by the sum of the free water content and the amount of water added to the sample. The degree of water saturation $\left(W_{\mathrm{s}}\right)$ is defined as

$$
W_{\mathrm{s}}(\%)=100 V_{\mathrm{w}} / V_{\mathrm{s}}
$$

Table 1 Some characteristics of the soil used in the dissolution experiment

\begin{tabular}{lc} 
Soil classification $^{\mathrm{a}}$ & $\begin{array}{c}\text { Fine textured Gray lawland soil } \\
\text { Soil horizon }\end{array}$ \\
Soil texture & Light clay $(\mathrm{LiC})$ \\
$\mathrm{pH}\left(\mathrm{H}_{2} \mathrm{O}\right)$ & 5.7 \\
True specific gravity & 2.64 \\
Major element composition & \\
(wt. \%, air-dried basis) $^{\mathrm{b}}$ & \\
$\quad \mathrm{SiO}_{2}$ & 59.5 \\
$\mathrm{TiO}_{2}$ & 0.85 \\
$\mathrm{Al}_{2} \mathrm{O}_{3}$ & 17.8 \\
$\mathrm{Fe}_{2} \mathrm{O}_{3}{ }^{\mathrm{c}}$ & 7.19 \\
$\mathrm{MnO}_{\mathrm{MgO}}$ & 0.10 \\
$\quad \mathrm{CaO}$ & 1.05 \\
$\mathrm{Na}_{2} \mathrm{O}$ & 1.19 \\
$\mathrm{~K}_{2} \mathrm{O}$ & 1.37 \\
$\mathrm{P}_{2} \mathrm{O}_{5}$ & 1.76 \\
$\mathrm{LOI}^{\mathrm{d}}$ & 0.20 \\
Organic carbon $(\text { wt. } \%)^{\mathrm{e}}$ & 9.05 \\
Moisture content $(\text { wt. \% })^{\mathrm{f}}$ & 1.86 \\
\hline
\end{tabular}

a. Reported by Yuita et al. ${ }^{17}$

b. Measured by X-ray fluorescence spectroscopy (Rigaku ZSX-101e). c. Total iron as $\mathrm{Fe}_{2} \mathrm{O}_{3}$.

d. Loss on ignition at $980^{\circ} \mathrm{C}$ for $3 \mathrm{~h}$.

e. Measured according to a method developed by Froelich. ${ }^{18}$

f. Obtained from weight loss by drying at $110^{\circ} \mathrm{C}$ overnight.

where $V_{\mathrm{w}}$ is the total volume of water in the soil and $V_{\mathrm{s}}$ is the volume of soil. The degree of water saturation was varied by the amount of Milli-Q water added to the soil. The total water amount mixed with the soil was $3.10 \mathrm{~g}, 4.55 \mathrm{~g}, 5.99 \mathrm{~g}$, and 7.44 g to prepare $100 \%, 140 \%, 180 \%$, and $220 \%$ of $W_{s}$, respectively. The sample names used in this study were W-100, W-140, etc. Above $140 \%$, the water was flooded on the soil surface. These samples were incubated at $25^{\circ} \mathrm{C}$ for 21 days. Eh and $\mathrm{pH}$ were measured by a platinum electrode and a glass electrode (Fujiwara Sci. Com., EHS-120), respectively, inserted at a depth of a few $\mathrm{cm}$ from the surface of the soil. Before sampling the soil solution, Milli-Q water was added and shaken for every sample to keep the water-soil ratio identical to the sample of W220. For example, $4.34 \mathrm{~g}$ of water $(=7.44 \mathrm{~g}-3.10 \mathrm{~g})$ was added to the W-100 sample just before sampling. After being centrifuged for $20 \mathrm{~min}$ at $3000 \mathrm{rpm}$, the soil solution was immediately recovered by filtration $(0.45 \mu \mathrm{m}$ membrane filter $)$. The $\mathrm{As}(\mathrm{III}) / \mathrm{As}(\mathrm{V})$ ratio in the extracted soil solution was immediately measured by HPLC-ICP-MS. The soil sample after recovering the soil solution was kept frozen until the XANES measurement at PF. XANES measurements could be conducted directly to frozen samples in plastic bottles. It is considered that the signal from arsenic in the aqueous phase is negligible in the XANES spectra, since the arsenic concentration in water is less than $10 \mu \mathrm{g} / \mathrm{dm}^{3}$, which is much smaller than the arsenic concentration in soil ( $\geqq 10 \mathrm{mg} / \mathrm{kg}$ ).

\section{Abundances of arsenic, $\mathrm{Fe}$, and $\mathrm{Mn}$}

The total amount of arsenic in the extracted soil solution was determined by ICP-MS (VG PQ-3) after adjusting the solution to a $2 \% \mathrm{HNO}_{3}$ solution. The internal standard was $\mathrm{Ge}-73$ and In-115. The contribution of ${ }^{40} \mathrm{Ar}^{35} \mathrm{Cl}$ to mass number 75 was negligible for all samples measured in this study. The manganese concentration in the soil solution was also measured by ICP-MS using Ge-73 as an internal standard, while the iron 


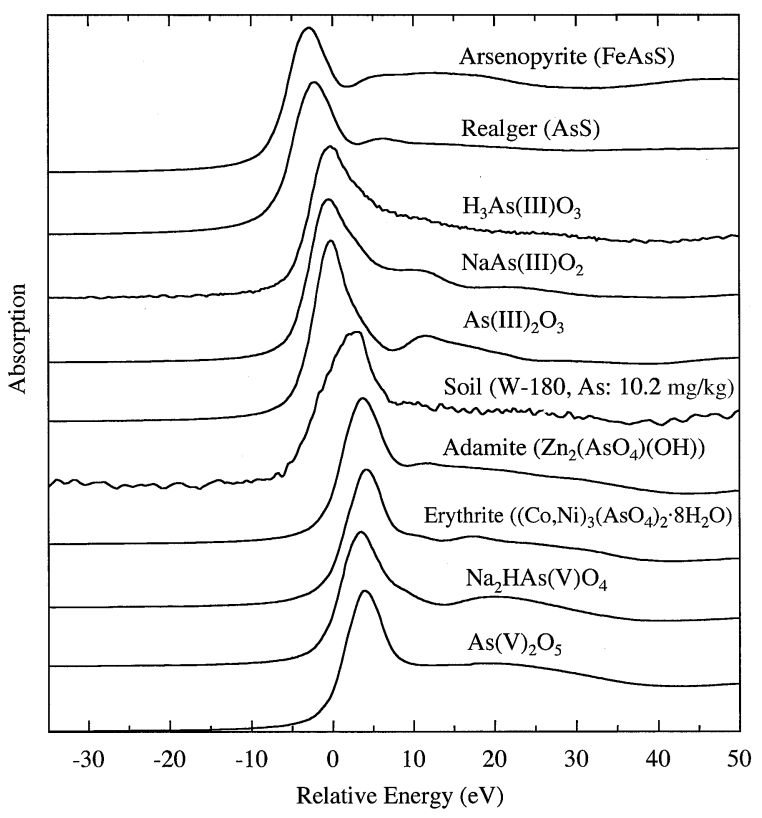

Fig. 1 Arsenic K-edge XANES spectra of reference materials $\left(\mathrm{H}_{3} \mathrm{AsO}_{3}, \mathrm{NaAsO}_{2}, \mathrm{As}_{2} \mathrm{O}_{3}, \mathrm{Na}_{2} \mathrm{HAsO}_{4}, \mathrm{As}_{2} \mathrm{O}_{5}\right)$, natural minerals (arsenopyrite, realger, adamite, erythrite), and a soil sample (W-180). The horizontal axis is the energy of the incident $\mathrm{X}$-rays relative to the energy at the peak maximum of the white line of $\mathrm{As}_{2} \mathrm{O}_{3}(11.866 \mathrm{keV})$.

concentration was determined by atomic absorption spectroscopy using the graphite-furnace method (GF-AAS; Jarrell Ash AA-8200).

\section{Results and Discussion}

\section{XANES spectra of various arsenic species}

Arsenic K-edge XANES spectra of some reference materials and arsenic minerals are shown in Fig. 1. The arsenic concentrations were adjusted below $1 \%$ for every sample by diluting with $\mathrm{SiO}_{2}$ powder. It is obvious that the absorption edge shifts to a higher energy when the oxidation state of arsenic is larger. This can be qualitatively explained by the larger attraction force between an electron and a nucleus for the ion at a larger oxidation state. This suggests that the position of the XANES peak can be used to distinguish As(III) bonding to $\mathrm{O}, \operatorname{As}(\mathrm{V})$ bonding to $\mathrm{O}$, and other arsenic minerals boding to $\mathrm{S}$ and $\mathrm{Fe}$ (arsenopyrite and realger) shown in Fig. 1.

An example of the spectrum of a soil sample (W-180) is also included in Fig. 1. It must be noted that the spectrum was obtained for $10.2 \mathrm{mg} / \mathrm{kg}$ arsenic, showing that the fluorescence XANES using 19-element SSD is quite sensitive for arsenic in soil. The sample was the most reductive one $(\mathrm{Eh}=154 \mathrm{mV}, \mathrm{pH}$ 5.53) among those which we studied (Fig. 6). The peak maximum of the sample exists between those of As(III) and $\mathrm{As}(\mathrm{V})$ species. This suggests that the sample W-180 contains both the $\mathrm{As}(\mathrm{III})$ and $\mathrm{As}(\mathrm{V})$ species. The feature at around 11 $12 \mathrm{eV}$ in the $\mathrm{As}_{2} \mathrm{O}_{3}$ spectrum was not found in the sample. A similar structure also observed in $\mathrm{As}_{2} \mathrm{~S}_{3}$ was interpreted theoretically. ${ }^{20}$ Hence, we employed sodium salts $\left(\mathrm{NaAsO}_{2}\right.$ and $\mathrm{Na}_{2} \mathrm{HAsO}_{4}$ ) to prepare a calibration line to estimate the oxidation state of arsenic in soil samples. The As(III) standard solution (Spex CentriPrep, Inc.) can also be a reference material for $\mathrm{As}(\mathrm{III})$, the chemical form of which is presumably $\mathrm{H}_{3} \mathrm{AsO}_{3}$ in a solution based on the Eh-pH diagram of arsenic. ${ }^{10,21}$

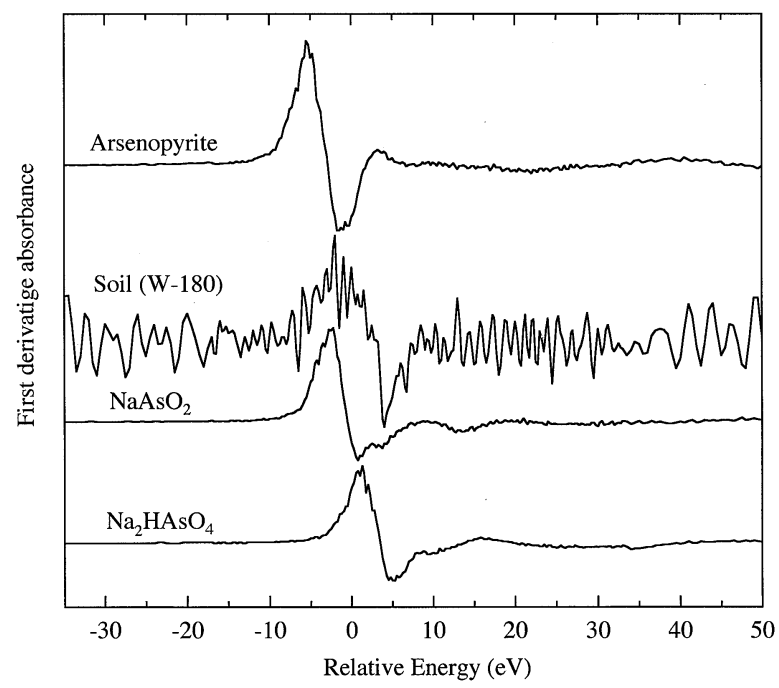

Fig. 2 First derivative of the XANES spectra of $\mathrm{NaAsO}_{2}$, $\mathrm{Na}_{2} \mathrm{HAsO}_{4}$, arsenopyrite, and a soil sample (W-180).

However, we did not use the solution to prepare reference materials, since (1) the $\mathrm{As}(\mathrm{III}) / \mathrm{As}(\mathrm{V})$ ratio may change during the mixing of $\mathrm{As}(\mathrm{III})$ and $\mathrm{As}(\mathrm{V})$ solutions and (2) the determination of the $\mathrm{As}(\mathrm{III}) / \mathrm{As}(\mathrm{V})$ ratio in solid media is the purpose of this study. Thus, we employed $\mathrm{NaAsO}_{2}$ and $\mathrm{Na}_{2} \mathrm{HAsO}_{4}$ as reference materials for $\mathrm{As}(\mathrm{III})$ and $\mathrm{As}(\mathrm{V})$ species. The energy of the peak maximum of the white line was similar among $\mathrm{NaAsO}_{2}, \mathrm{H}_{3} \mathrm{AsO}_{3}$, and $\mathrm{As}_{2} \mathrm{O}_{3}$, suggesting that the $\mathrm{As}(\mathrm{III}) / \mathrm{As}(\mathrm{V})$ ratio determined by XANES analysis would be similar by employing any three of the materials used as As(III) species. In the soil sample (W-180), the contribution of arsenopyrite, the most abundant arsenic mineral in ores, is not important, as can be seen from the spectra. This fact was also supported by the first derivative of the spectra (Fig. 2), where the contributions of As(III) and As(V) were indicated by the soil spectrum, while that of arsenopyrite was slight. This is consistent with previous studies showing that the major arsenic species are the $\mathrm{As}(\mathrm{III})$ and $\mathrm{As}(\mathrm{V})$ species contained in the metal oxides, particularly those of $\mathrm{Fe}, \mathrm{Al}$, and $\mathrm{Mn}$, in soils in the environment. ${ }^{1,2}$

\section{Determination of the $A s(I I I) / A s(V)$ ratio in the solid phase}

We can estimate the $\mathrm{As}(\mathrm{III}) / \mathrm{As}(\mathrm{V})$ ratio from the XANES spectrum based on a proper analysis of the spectrum. In this study, the $\mathrm{As}(\mathrm{III}) / \mathrm{As}(\mathrm{V})$ ratio in the solid phase was determined by fitting the sample spectrum by the reference materials, $\mathrm{NaAsO}_{2}$ and $\mathrm{Na}_{2} \mathrm{HAsO}_{4}$. Mixtures of reference materials containing $0 \%, 18.9 \%, 38.2 \%, 58.2 \%, 78.9 \%$, and $100 \%$ of As(III) among the total arsenic species, As(III) + As(V), were prepared and diluted by $\mathrm{SiO}_{2}$ powder. The total concentration of arsenic was adjusted to $1.0 \%$. The mixed sample was kept in a plastic bag, where the oxygen content was regulated at $\mathrm{O}_{2}<$ $0.1 \%$ by oxygen absorbers.

The variation in the XANES spectra for mixtures of $\mathrm{NaAsO}_{2}$ and $\mathrm{Na}_{2} \mathrm{HAsO}_{4}$ are shown in Fig. 3. These spectra were fitted by the spectra of the end members, $\mathrm{NaAsO}_{2}$ and $\mathrm{Na}_{2} \mathrm{HAsO}_{4}$. Before the fitting procedure, each spectrum of $\mathrm{NaAsO}_{2}$ and $\mathrm{Na}_{2} \mathrm{HAsO}_{4}$ was normalized based on the EXAFS spectra by defining the absorption between 500 and $900 \mathrm{eV}$ as one. The spectra of the mixtures ( $\mu$ t(mixtures)) were simulated by a linear combination of the normalized spectra of $\mathrm{NaAsO}_{2}$ and 


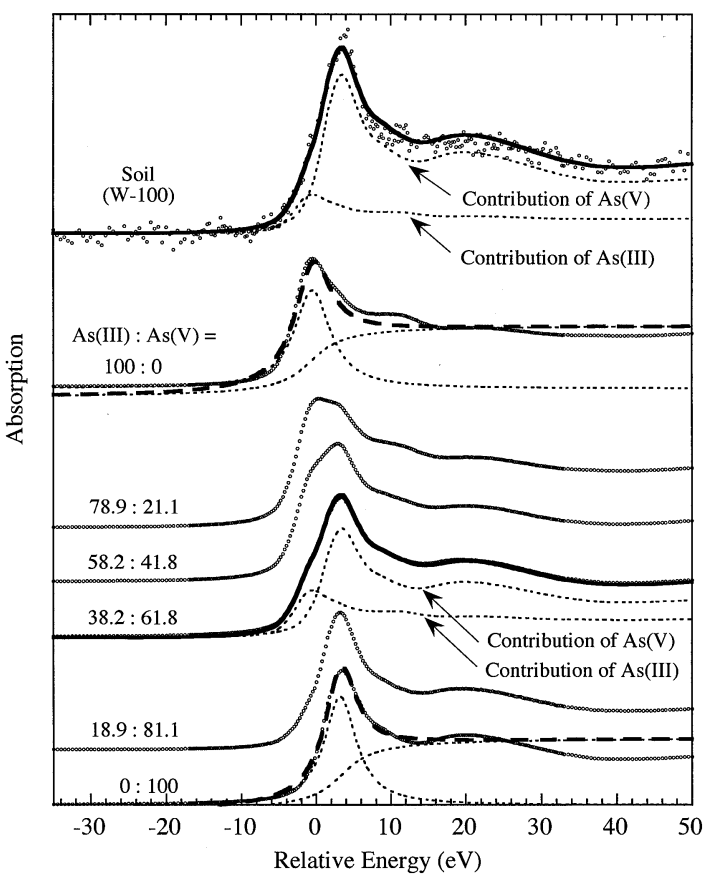

Fig. 3 Arsenic K-edge XANES spectra of a soil sample (W-100) and mixtures of $\mathrm{NaAsO}_{2}$ and $\mathrm{Na}_{2} \mathrm{HAsO}_{4}$. The mixing ratios for the mixtures are indicated in the figure. Least-squares fittings by the spectra of $\mathrm{NaAsO}_{2}$ and $\mathrm{Na}_{2} \mathrm{HAsO}_{4}$ are shown for a sample and a mixture containing $38.2 \%$ of As(III). The solid curves indicate the spectra obtained by the simulation, while dashed curves show the contributions of $\mathrm{As}(\mathrm{III})$ and $\mathrm{As}(\mathrm{V})$. The results show that these spectra can be well fitted by those of $\mathrm{NaAsO}_{2}$ and $\mathrm{Na}_{2} \mathrm{HAsO}_{4}$. The deconvolutions of $\mathrm{NaAsO}_{2}$ and $\mathrm{Na}_{2} \mathrm{HAsO}_{4}$ spectra conducted by the combination of a Lorentzian and an arctangent functions were also shown.

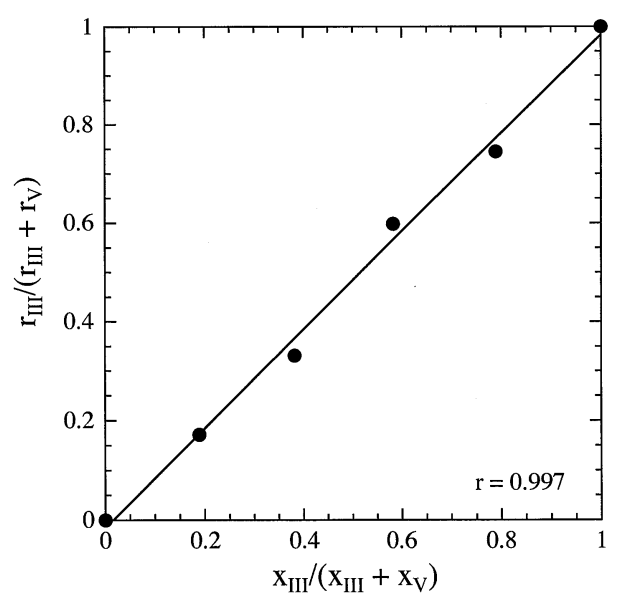

Fig. 4 Relationship between the molar ratio of $\mathrm{As}(\mathrm{III})\left(=x_{\mathrm{III}} /\left(x_{\mathrm{III}}+\right.\right.$ $\left.X_{\mathrm{V}}\right)$ ) and the ratio of coefficients multiplied to the spectra of $\mathrm{NaAsO}_{2}$ and $\mathrm{Na}_{2} \mathrm{HAsO}_{4}$ to simulate those of mixtures $\left(=r_{\mathrm{II}} /\left(r_{\mathrm{III}}+r_{\mathrm{V}}\right)\right)$ as indicated in Eq. (2). A line obtained by a least-squares analysis was indicated with the correlation coefficient $(r)$.

$\mathrm{Na}_{2} \mathrm{HAsO}_{4}\left(\mu \mathrm{t}_{\mathrm{N}}\left(\mathrm{NaAsO}_{2}\right)\right.$ and $\mu \mathrm{t}_{\mathrm{N}}\left(\mathrm{Na}_{2} \mathrm{HAsO}_{4}\right)$, respectively):

$$
\mu \mathrm{t}(\text { mixtures })=r^{\mathrm{II}} \mu \mathrm{t}_{\mathrm{N}}\left(\mathrm{NaAsO}_{2}\right)+r^{\mathrm{V}} \mu \mathrm{t}_{\mathrm{N}}\left(\mathrm{Na}_{2} \mathrm{HAsO}_{4}\right),
$$

where $r^{\mathrm{III}}$ and $r^{\mathrm{V}}$ are coefficients showing the contributions of

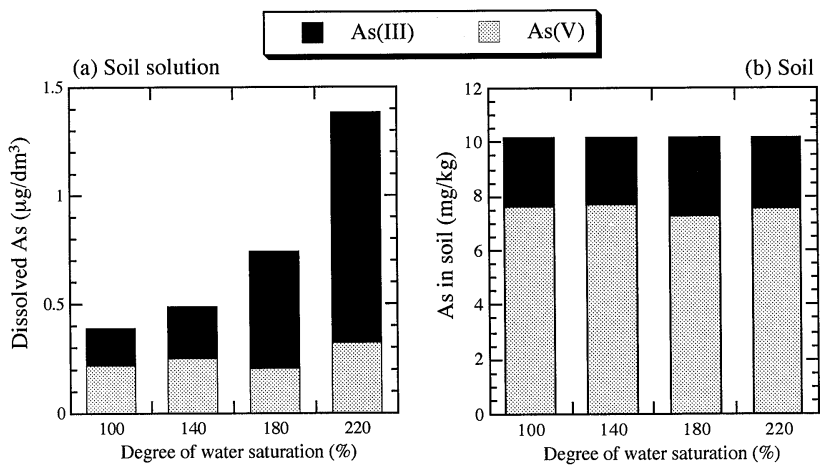

Fig. 5 Concentrations of $\mathrm{As}(\mathrm{III})$ and $\mathrm{As}(\mathrm{V})$ in (a) soil solution and (b) soil at different degrees of water saturation. The definition of the degree of water saturation is given in the text.

As(III) and As(V). A simulation was conducted by a leastsquares fitting in the $-15 \mathrm{eV}$ and $20 \mathrm{eV}$ region using a routine, Solver, supplied with Microsoft Excel. The spectra of the mixtures were well-fitted by the model (Fig. 3). The $r^{\mathrm{III}} /\left(r^{\mathrm{III}}+\right.$ $r^{\mathrm{V}}$ ) values were identical to the molar ratio of $\mathrm{As}(\mathrm{III})$ and $\mathrm{As}(\mathrm{V})$, $x^{\mathrm{III}} /\left(x^{\mathrm{III}}+x^{\mathrm{V}}\right)$, as shown in Fig. 4. This shows that the $\mathrm{As}(\mathrm{III}) / \mathrm{As}(\mathrm{V})$ ratio can be determined by a simulation using normalized spectra of $\mathrm{NaAsO}_{2}$ and $\mathrm{Na}_{2} \mathrm{HAsO}_{4}$, if we can consider that $\mathrm{As}(\mathrm{III})$ and $\mathrm{As}(\mathrm{V})$ are the main species in soil. The error defined as the square root of the unbiased variance obtained from the difference between the measured value and the estimated value given by the regression line in Fig. 4 was 0.04 for $x^{\mathrm{III}} /\left(x^{\mathrm{III}}+x^{\mathrm{V}}\right)$.

Deconvolutions of the normalized spectra of $\mathrm{NaAsO}_{2}$ and $\mathrm{Na}_{2} \mathrm{HAsO}_{4}$ were conducted by combining a Lorentzian and an arctangent functions. The area of the white line expressed by the Lorentzian function was 5.13 and $5.08(\mathrm{eV} \times$ absorption intensity in normalized spectra) for $\mathrm{NaAsO}_{2}$ and $\mathrm{Na}_{2} \mathrm{HAsO}_{4}$, respectively, showing that the two peak areas are quite similar to each other. This implies that the absorption cross section for the electron transition which produces the white line is similar between the $\mathrm{As}(\mathrm{III})$ and $\mathrm{As}(\mathrm{V})$ species, though the absorption cross section can vary among different oxidation states, as observed in the case of sulfur. ${ }^{11,12}$ This suggests that the $\mathrm{As}(\mathrm{III}) / \mathrm{As}(\mathrm{V})$ ratio can also be determined by the deconvolution of an unknown spectrum by two pairs of a Lorentzian and an arctangent functions, where the $\mathrm{As}(\mathrm{III}) / \mathrm{As}(\mathrm{V})$ ratio can be directly obtained from the peak area of two Lorentzian functions.

The application of XANES to soil samples in soil incubation experiments

The arsenic K-edge XANES spectra of a soil sample (W-100) prepared in this study are shown in Fig. 3 along with the fitting result, suggesting that the simulation using the model compounds employed in the fitting can give a good agreement with the spectrum of the soil sample. This suggests that the $\mathrm{As}(\mathrm{III})$ and $\mathrm{As}(\mathrm{V})$ ratio in soil can be estimated by XANES, as conducted in this study. Coupled with HPLC-ICP-MS used for the arsenic species in solution, the $\mathrm{As}(\mathrm{III})$ and $\mathrm{As}(\mathrm{V})$ concentrations in both the aqueous and solid phases were determined (Fig. 5). It is clear that the $\mathrm{As}(\mathrm{III}) / \mathrm{As}(\mathrm{V})$ ratio in soil is rather similar for every sample, while the contribution of As(III) increases with an increase in the degree of water saturation (Ws) in a soil solution. The Eh value decreases with an increase in Ws, which is consistent with the larger 

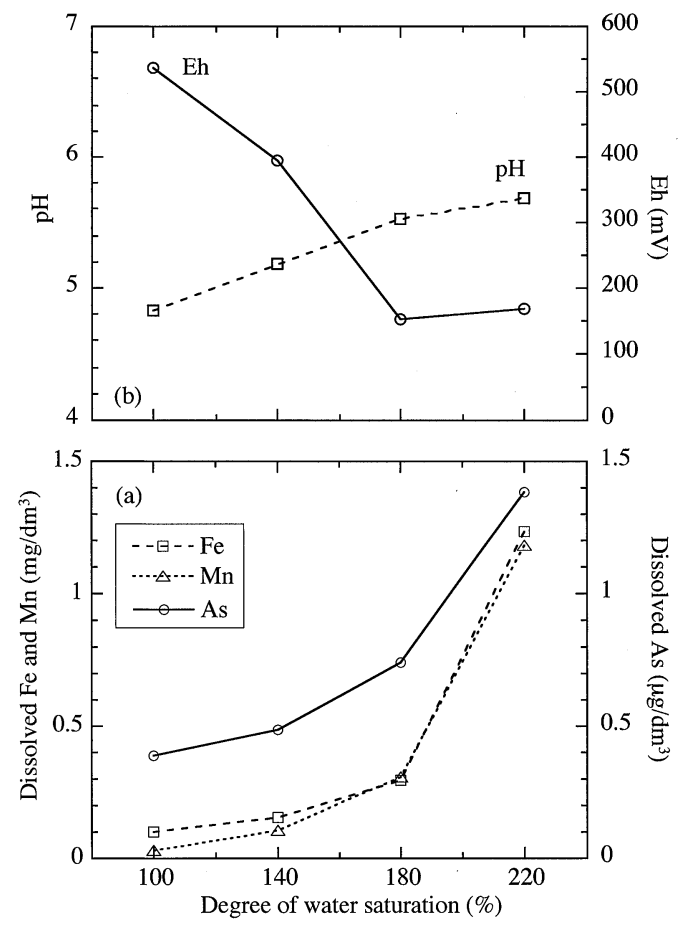

Fig. 6 Concentrations of dissolved Fe, Mn, and total arsenic in (a) soil solution with (b) Eh and $\mathrm{pH}$ condition in water at different degrees of water saturation.

$\mathrm{As}(\mathrm{III}) / \mathrm{As}(\mathrm{V})$ ratio in a soil solution (Fig. 6b). The total concentration of arsenic dissolved in the aqueous phase increased with an increase of Ws. The behavior of arsenic in the aqueous phase is quite similar to those of Fe and Mn (Fig. 6a). This strongly suggests that arsenic is dissolved in a soil solution by the dissolution of $\mathrm{Fe}$ and $\mathrm{Mn}$ (hydr)oxides containing a large amount of arsenic, as reported in many studies. ${ }^{1,6,8,9}$ In addition, the high mobility of As(III) has been thought to be another factor to cause a high concentration of arsenic in water under a reductive condition., ${ }^{1,6,8,9}$ The distribution coefficients, $K_{\mathrm{d}}(\mathrm{ml} / \mathrm{g})$, independently determined for $\mathrm{As}(\mathrm{III})$ and $\mathrm{As}(\mathrm{V})$ based on the present methods suggest that $\mathrm{As}(\mathrm{III})$ is distributed in soil more readily than As(V) (Fig. 7). This supports that As(III) is more mobile in the soil-water system, as has been inferred in many studies. ${ }^{1,2}$ The establishment of appropriate methods to independently determine the distribution coefficients for $\mathrm{As}(\mathrm{III})$ and $\mathrm{As}(\mathrm{V})$ is a prerequisite to comparing these two factors. XANES is a powerful technique that enables us to determine As(III) and $\mathrm{As}(\mathrm{V})$ species quantitatively in soil and other solid media.

\section{Conclusions}

This paper describes the details of a method used to determine the As(III)/As(V) ratio by XANES in solid media like soil. The $\mathrm{K}$-edge XANES of arsenic in soil can be well simulated by a linear combination of $\mathrm{NaAsO}_{2}$ and $\mathrm{Na}_{2} \mathrm{HAsO}_{4}$ used as reference materials of the $\mathrm{As}(\mathrm{III})$ and $\mathrm{As}(\mathrm{V})$ species, respectively. The ratio of the coefficients multiplied by the normalized spectra of $\mathrm{NaAsO}_{2}$ and $\mathrm{Na}_{2} \mathrm{HAsO}_{4}$ to simulate the spectra of mixtures of $\mathrm{NaAsO}_{2}$ and $\mathrm{Na}_{2} \mathrm{HAsO}_{4}$ was identical to the molar ratio of $\mathrm{As}(\mathrm{III})$ and $\mathrm{As}(\mathrm{V})$, suggesting that the $\mathrm{As}(\mathrm{III}) / \mathrm{As}(\mathrm{V})$ ratio can be directly determined by the mixing ratio of the normalized spectra. The method was successfully employed to determine

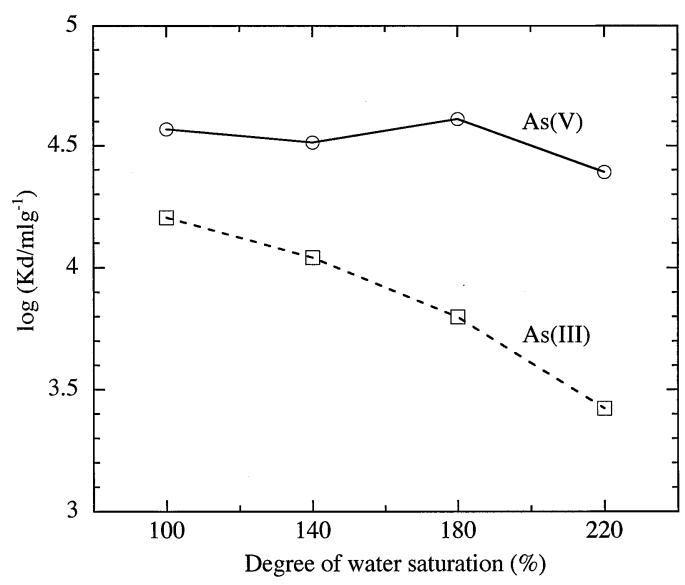

Fig. 7 Distribution ratios, $K_{\mathrm{d}}(\mathrm{ml} / \mathrm{g})$, of $\mathrm{As}(\mathrm{III})$ and $\mathrm{As}(\mathrm{V})$ between soil and soil solution at different degrees of water saturation.

the $\mathrm{As}(\mathrm{III}) / \mathrm{As}(\mathrm{V})$ ratio in soil, where the arsenic content was $10.2 \mathrm{mg} / \mathrm{kg}$, showing that the fluorescence XANES using 19element SSD is sensitive enough to conduct arsenic speciation in natural solid media. The XANES coupled with the speciation method in water (HPLC-ICP-MS or atomic absorption spectroscopy with hydride generation) can be a powerful tool to estimate the behavior of arsenic in a natural aquifer based on the independent information of $\mathrm{As}(\mathrm{III})$ and $\mathrm{As}(\mathrm{V})$.

\section{Acknowledgements}

We thank Dr. Y. Okamoto for help with the GF-AAS measurements and Dr. Rupa Bhattacharyya for providing fruitful comments on this paper. Our thanks are extended to Mr. N. Sakakibara for his great contribution to this study. This research was supported by a Grant-in-Aid for scientific research from the Ministry of Education, Science, Sports, and Culture of Japan, and by funds from Hiroshima University Fund for Environmental Science. This work has been performed with the approval of KEK (Proposal No. 2002G243).

\section{References}

1. P. L. Smedley and D. G. Kinniburgh, Appl. Geochem., 2002, 17, 517.

2. F. R. Siegeal, "Environmental geochemistry of potentially toxic metals", 2002, Springer, Berlin.

3. R. T. Nickson, J. M. McArthur, W. G. Burgess, K. M. Ahmed, P. Ravenscroft, and M. Rahman, Nature, 1998 395, 338 .

4. M. Morita and J. S. Edmonds, Pure Appl. Chem., 1992, 64, 575.

5. M. K. Donais, Spectroscopy, 1998, 9, 30.

6. B. M. Onken and L. R. Hossner, Soil Sci. Soc. Am. J., 1996, 60, 1385.

7. A. L. Foster, G. E. Brown Jr., T. N. Tingle, and G. A. Parks, Am. Mineral., 1998, 83, 553.

8. J. G. Reynolds, D. V. Naylor, and S. E. Fendorf, Soil Sci. Soc. Am. J., 1999, 63, 1149.

9. E. A. Rochette, G. C. Li, and S. E. Fendorf, Soil Sci. Soc Am. J., 1998, 62, 1530.

10. P. E. Kneebone, P. A. O'Day, N. Jones, and J. G. Hering, 
Environ. Sci. Technol., 2002, 36, 381.

11. G. S. Waldo, R. M. K. Carlson, J. M. Moldowan, K. E. Petters, and J. E. Penner-Hahn, Geochim. Cosmochim. Acta, 1991, 55, 801.

12. K. Xia, F. Weesner, W. F Bleam, P. R. Bloom, U. L. Skyllberg, and P. A. Helmke, Soil Sci. Soc. Am. J., 1998 , 62,1240 .

13. M. Nomura and A. Koyama, KEK-Report, 1996, 95-15.

14. M. Nomura, J. Synchrotron Rad., 1998, 5, 851.

15. M. Nomura, KEK-Report, 1998, 98-4.

16. K. Yuita, T. Tanaka, C. Abe, and S. Aso, Soil Sci. Plant
Nutr., 1991, 37, 61.

17. K. Yuita, Jpn. J. Soil Sci. Plant Nutr (in Japanese)., 2002, 73, 57.

18. P. N. Froelich, Limnol. Oceanol., 1980, 25, 564.

19. Y. Takahashi, R. Minamikawa, K. H. Hattori, K. Kurishima, N. Kihou, and K. Yuita, 2003, submitted.

20. G. Pfeiffer, J. J. Rehr, and D. E. Sayers, Phys. Rev. B, 1995, 51,804

21. D. G. Brookins, "Eh-pH diagrams for geochemistry", 1987, Springer, Berlin. 